\title{
INTEGRATING DISRUPTIVE INNOVATION, COMPETITIVE ADVANTAGE, AND BUSINESS NETWORKING CAPABILITY ON SMALL BUSINESS PERFORMANCE IN INDONESIA
}

\author{
Sri Murni Setyawati ${ }^{1}$, Monica Rosiana ${ }^{2 *}$, dan Wiwiek Rabiatul Adawiyah ${ }^{3}$ \\ 1,2,3 Fakultas Ekonomi dan Bisnis, Universitas Jenderal Soedirman \\ *Email corresponding author : monica_rosiana@yahoo.com
}

\begin{abstract}
This study aimed at explaining the influence of disruptive innovation on business performance with competitive advantage as a mediator and networking capability as moderate. The tool of analysis used was Structural Equation Modelling (SEM). The sample size of this research was 120 owners and/or managers of Small and Medium Enterprises (SMEs) in the Purwokerto areas. The result showed that disruptive innovation has a positive effect on both business performance and competitive advantage. The study supported the view that competitive advantage has a positive impact on business performance. Also, competitive advantage act as mediating variable on the relationship between disruptive innovation and business performance. Finally, the last hypothesis stated that networking as moderation variable of disruptive innovation to business performance was supported.
\end{abstract}

Keywords: disruptive innovation, competitive advantage, networking, business performance

\begin{abstract}
ABSTRAK
Penelitian ini bertujuan untuk menjelaskan pengaruh inovasi disruptif pada kinerja bisnis dengan keunggulan kompetitif sebagai mediator dan kemampuan jaringan sebagai moderat. Alat analisis yang digunakan adalah Structural Equation Modeling (SEM). Ukuran sampel dari penelitian ini adalah 120 pemilik dan / atau manajer Usaha Kecil dan Menengah (UKM) di wilayah Purwokerto. Hasil penelitian menunjukkan bahwa inovasi disruptif memiliki efek positif pada kinerja bisnis dan keunggulan kompetitif. Studi ini mendukung pandangan bahwa keunggulan kompetitif memiliki dampak positif pada kinerja bisnis. Juga, keunggulan kompetitif bertindak sebagai variabel penengah pada hubungan antara inovasi disruptif dan kinerja bisnis. Akhirnya, hipotesis terakhir yang menyatakan bahwa jaringan sebagai variabel moderasi dari inovasi disruptif ke kinerja bisnis ,diterima.
\end{abstract}

Kata kunci: inovasi disruptif, keunggulan kompetitif, jaringan, kinerja bisnis

\section{INTRODUCTION}

Academic interest on small business inquiries in Indonesia is growing pervasively. This is due to the fact that the business tendency index or optimism level index in quarter III2015 was predicted to be 106,09 which means that business condition was better than the previous quarter. Economic and political institutions have high expectations that small business growth will encourage more individuals to become entrepreneurs and will thus foster an entrepreneurial spirit in a country (Shane, 2009). Small business firms play a pivotal role in economic development in terms of innovation, job creation, and economic growth. Small business owners who invested in technology believe that the investment shall effectively increase their competitive advantage in the market. 
The technological challenge faced by small businesses can be seen as either a business threat or opportunities. For those who obsess to grow, the investment is an opportunity in disguise that should be active on as a way to survive in the future. Others, with financial constraint, would see disruptive innovation as a threat that would terminate their business. To survive a firm is forced to choose the right decision and prepare for the appropriate strategy.

To achieve an optimum business performance, a firm should adopt the out of box innovation, so-called disruptive innovation. This term was created by Clayton M. Christensen and Joseph Bower in 1995. According to them, disruptive innovation is an innovation that helps create a new market, disturbs or breaks the existing market and finally replaces the previous technology. This innovation is carried out by creating different types of customers in the new market and reducing the old market price.

According to Hashi and Stojcic (2012), Espallardo and Elena (2009), Junior, Pinheiro, and Valeri (2015), the correlation between innovation and business performance is the higher the company innovation, the higher the business performance of the company. They also suggest that thus far innovation is still an activity that creates most of the core value and competitive weapon operating in national and international business. However, there is another view from the result of the research conducted by Isogava (2012). He argues that innovation does not necessarily improve firm performance because of so called cannibalization effect. Only radical innovation can improve firm performance since the increase in demand comes from the fact that completely new products benefit consumers higher compare to the previous ones. He also explains that high innovation, both the innovation of process or product, will be able to improve business performance through competitive advantage.

According to Letycja (2014),, competitive advantage is organization ability to formulate the strategy that puts them in an advantageous position related to other companies. Competitive Advantage appears if customers feel that they receive more value from a transaction with competitors. Competitive advantage can be mediation variable of the effect of disruptive innovation on business performance. Innovation that has been done by the company will influence the selection of marketing strategy so that the quality and quantity of the product are getting better. It will encourage the company to achieve business performance through competitive advantage. Further, Sylvia, et al (2015) suggest that to deliver business performance, the company should have an excellent capability for networking. Business networking is an essential variable for all kinds of the company because it will facilitate the company to access information, human resources, market, and technology (Hakimpoor, 2011). Therefore, competitive advantage is included in this research as mediation variable and business networking capability as moderation variable of the effect of disruptive innovation on business performance.

Based on the explanation above, small and medium enterprises are a suitable sample for this research. Only effective marketing could help SME's to gain performance via competitive advantage and relationship marketing strategy (Yan and Chew, 2011). Marketing strategy can benefit the small firms to become a large firms while emphasizing on networking as an inherent tool of marketing (Gilmore et al., 2001). Duncan (2000) clarifies that there is a limited number of research on business performance at Small and Medium Enterprises. It is because there is an assumption that SMEs is challenging to be studied since it does not have an optimum organization culture. However, behind this weakness, there is an advantage when a researcher investigates small and medium enterprises, the result will be clear because the products are not varied and bias can be reduced. Therefore, the researcher was interested in carrying out an empirical study on the small and medium enterprise in Purwokerto Central Java Indonesia. 
The results of the researches that examine the effect of innovation on business performance are varied. The research conducted by Hashi and Stojcic (2012), Espallardo and Elena (2009), Junior, Pinheiro, and Valeri (2015). However, there is another view from the research conducted by Isogava (2012).

The reason is that innovation performed by a company will increase value for customers and cost for the company at the same time such as the cost for marketing research and marketing experts. Therefore, based on the suggestions of the previous inquiries, this research will add competitive advantage as mediation and business networking capability as moderation.

\section{LITERATURE REVIEW AND HYPOTHESIS DEVELOPMENT}

In business, a disruptive innovation is an innovation that creates a new market and value network and eventually disrupts an existing market and value network. The term was defined and first analyzed by the American scholar Clayton M. Christensen and his collaborators beginning in 1995, and has been called the most influential business idea of the early 21st century. Hashi and Stojcic (2012) suggest that innovation can improve performance. In their research, the results indicate a significantly positive relationship between innovation and performance. Rosiana (2015) alleges that innovation is an effort done by a company to create a new product which aims to adapt to customers' favor and to escalate sales. Therefore, it can be said that the more the products are offered to customers, the more selective the customers buy a product either in the aspect of quality, pattern design, color, or price. Morales (2011) also suggests that business companies that have the innovative ability can face more competitive global environment and they will be able to achieve better business performance and growth. This notion is supported by Espallardo and Elena (2009), Junior, Pinheiro, and Valeri (2015) who argue that innovation is still one of the best strategies that can create a business performance for national or international companies. Xayphone and Takahashi (2009) in their research define that innovation can improve export competitiveness and continuous business performance. According to the Junior, Pinheiro, and Valeri (2015), correlation between innovation and business performance is the higher the innovation of a company, the higher the business performance. Therefore, the hypothesis is formulated as follows:

$\mathrm{H}_{1}$ : Disruptive Innovation has a positive effect on business performance.

In this global era, the competitive advantage becomes vital in developing a business in the future. Wang et al., (2015) suggests that a competitive advantage can be achieved by the company if the company gives more benefits than the competitors. This advantage is closely related to company ability to formulate strategy and put them into an advantageous position (Rosiana, 2015). Chen et al. (2009) state that innovation has a positive effect on competitive advantage. If a company creates an innovative product, they can reach their competitive advantage. Hana (2013) also suggests that innovation, as a result of creativity, knowledge, skill, and personal ability of employees, will encourage the company to achieve a competitive advantage. Noorani (2014) clarifies that innovation performed by the company affects the achievement of competitive advantage. According to her, there are many factors in innovation that can help the company achieve a competitive advantage. One of them is an innovation of technology. Research conducted by Chatzoglou, Chatzoudes (2018) suggests that there is evidence that innovation can make the company have more value than the competitors. Therefore, the hypothesis is formulated as follows:

$\mathrm{H}_{2}$ : Disruptive innovation has a positive effect on competitive advantage.

Rosiana (2015) suggests that business performance is a concept used to measure the market achievement reached by a product of the company. All company strategies are always directed to good business performance. A good business performance shows the more increase 
in the number of sales either in product unit or monetary unit. Wang et al. (2015) is successful to find the positive effect of competitive advantage on performance measured through sales volume, profit level, market share, and return on investment. The company that can create competitive advantage will have the power to compete with other companies since their products will still have more value than the competitors' product. Thus, a competitive advantage has a positive effect on the increase in company business performance. The result of the research conducted by Istanto (2010) concludes that competitive advantage after its the return of Koperasi Serba Usaha in Sleman regency. In other words, the better the competitive advantage will increase company performance. Supranoto (2009) in his research also concludes that competitive advantage produced by the company can enhance business performance. The company, which creates new quality product and service with lower cost, product improvisation with unique attributes, produces different products, will be able to improve its business performance. Therefore, the hypothesis is formulated as follows:

$\mathrm{H}_{3}$ : Competitive advantage has a positive effect on business performance.

Pinheiro, and Valeri (2015) suggests that innovation will encourage the company to make and spread their ability that can support their long-term business performance. Successful innovation can make competitors find it more challenging to make imitation product, and it will enable the company to be able to maintain competitive advantage better (Morales et al., 2011). Therefore, innovation can influence competitive advantage, and if the advantage has been reached, business performance will increase (Wing won, 2012). It is also supported by Sakchutchawan, et al., (2011) that has proven that innovation has a positive and significant effect on competitive advantage. The result of his research shows that company willing to keep making innovation will give effect to the achievement of competitive advantage and it will give impact on performance. In his study, they also state that competitive advantage can be made as a mediator of the relationship between innovation and business performance. Therefore, the hypothesis is formulated as follows:

$\mathrm{H}_{4}$ : $\quad$ Competitive advantage mediates the relationship between innovation and business performance.

Recently, networking is getting more important since it facilitates the company to access information, resources, market, and technology. Small and Medium Enterprises, which combine e-commerce practices with traditional business management practices, will get a better position to be able to compete, use a brand that is easily recognized, the existing supply chain, and improve the relationship. Silanpaa, et al (2015) also suggests that closer relationship with suppliers gives strong contribution for company performance such as cost efficiency, quality improvement, reliability, and fulfillment of input need that is always available at any time. Relationship with the suppliers can improve information source about market development, new technology, and competitors' movement, either find potential partners or access to partners from other sectors. In other words, business networking can strengthen the correlation between innovation and business performance. Innovation done by the company will give more positive effect on the improvement of business performance since it is supported by business networking capability.

$\mathrm{H}_{5} \quad$ : Business networking capability moderates the relationship between innovation and business performance.

\section{RESEARCH METHOD}

The population of this research was all owners and/or managers of Small and Medium Enterprises in Purwokerto. The method used to collect the data was by distributing questionnaire with scale 1-7 and conducted a direct interview about the effect of innovation on business performance. Based on Hair, et al (2010), the minimum sample size is 100 . 
Therefore, it is suggested to have a sample size 5-10 times parameter. In this research, there were 16 indicators and 4 line coefficients so that the total estimated parameters were 20 parameters. Thus, the samples taken were 120 (20x6). To examine the empirical model, Structural Equation Modeling (SEM) was used. The other analysis tools used in this research were AMOS 21.0, SPSS 16.0 and Microsoft Excel 2007.

\section{RESULT AND DISCUSSION}

Based on the outcome of convergent validity test, it can be seen that all loading factors were statistically significant and the value of loading had been $\geq 0,60$. Therefore, it can be concluded that all indicators used were reliable so that they could be used for the next analysis step. The result of discriminant validity test also shows that all AVE values are higher than correlation square among constructs in all correlations of variables. Therefore, it can be concluded that the test result shows that all constructs that are used have good validity and can be used in the next analysis step.

The test result indicated that the model was fit. As shown in Table 1 that all the criteria, i.e., Chi-Square, Probability, CMIN/DF, GFI, AGFI, TLI, CFI, and RMSEA were proper. According to Hair, et al. (2010) goodness of fit test can be accepted, or the model is categorized "fit" if minimally five criteria are met.

Based on the result of SEM analysis in the model-goodness-of-fit test, eight criteria were obtained in category "good." Based on the result, the model in this research can be categorized as an excellent model or fit model.

Table 1. The Result of Goodness of Fit Test

\begin{tabular}{|c|c|c|c|}
\hline Index of Model Fit & Cut-off Value & Result of Analysis & Note \\
\hline$\chi^{2}-$ Chi-Square & $\begin{array}{l}<\chi^{2} 68,669 \\
(p 0,05 ; \text { df 24) }\end{array}$ & 53,911 & Good \\
\hline Probability & $\geq 0,05$ & 0,758 & Good \\
\hline CMIN/DF & $\leq 2,00$ & 0,870 & Good \\
\hline RMSEA & $\leq 0,08$ & 0,000 & Good \\
\hline GFI & $\geq 0,90$ & 0,942 & Good \\
\hline AGFI & $\geq 0,90$ & 0,914 & Good \\
\hline TLI & $\geq 0,95$ & 1,018 & Good \\
\hline CFI & $\geq 0,95$ & 1,000 & Good \\
\hline
\end{tabular}




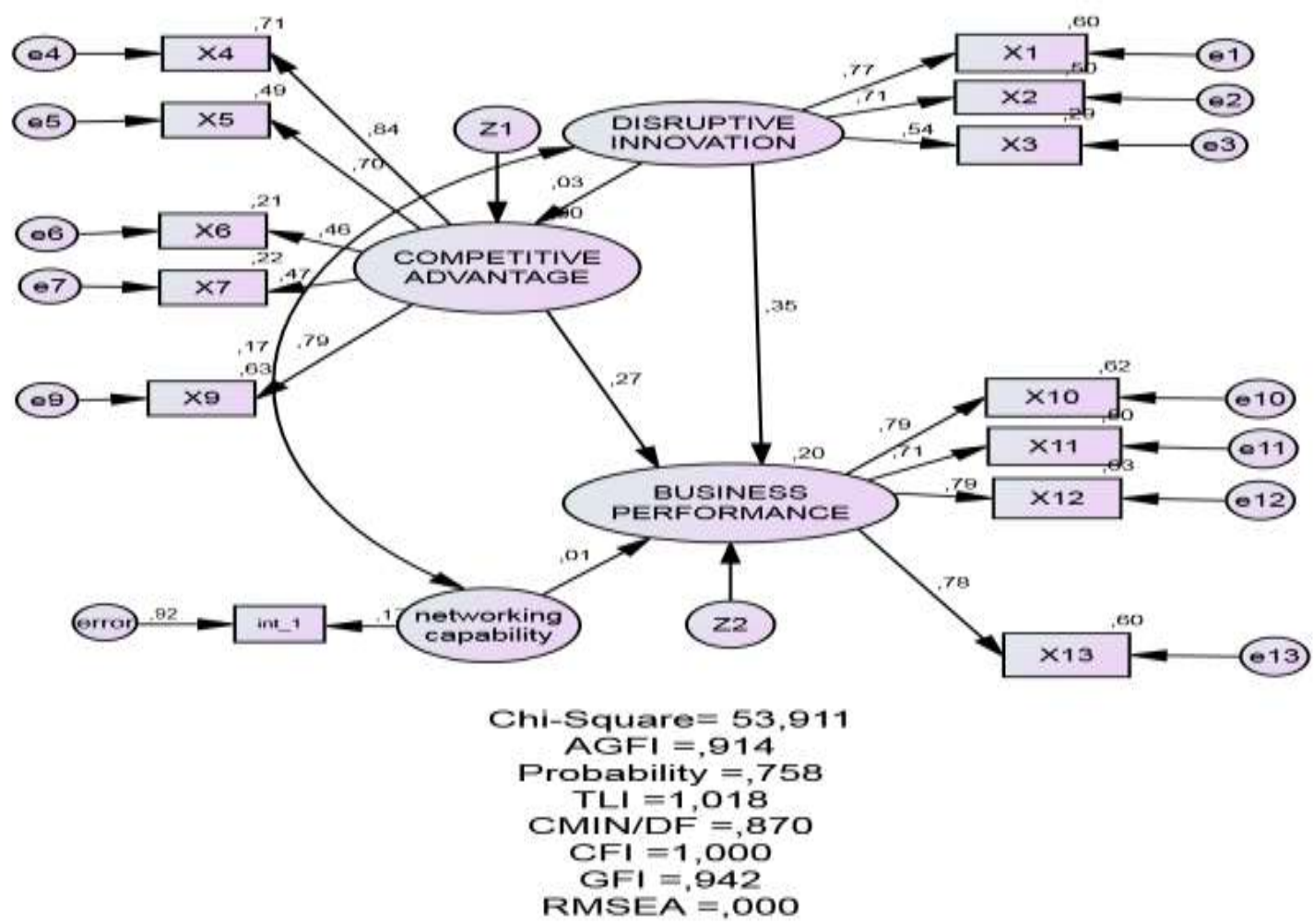

Figure 1 the result of SEM analysis on the model.

Table 2. The result of Hypothesis Testing

\begin{tabular}{|c|c|c|c|c|}
\hline Hypothesis & $\begin{array}{l}\text { Value } \\
\text { of C.R. }\end{array}$ & $\begin{array}{l}\text { Value } \\
\text { of } t_{\text {table }}\end{array}$ & $\mathbf{P}$ & $\begin{array}{l}\text { Test } \\
\text { Result }\end{array}$ \\
\hline $\begin{array}{l}\text { Disruptive Innovation } \\
\text { Competitive Advantage }\end{array}$ & 2,253 & 1,979 & 0,023 & Supported \\
\hline $\begin{array}{l}\text { Disruptive Innovation } \rightarrow \text { Business } \\
\text { Performance }\end{array}$ & 2,998 & 1,979 & 0,003 & Supported \\
\hline $\begin{array}{l}\text { Competitive Advantage } \rightarrow \text { Business } \\
\text { Performance }\end{array}$ & 2,636 & 1,979 & 0,008 & Supported \\
\hline
\end{tabular}

As indicated in table 2 that the result of the hypothesis testing reported that all hypothesis was supported because the p-value is less than 0.05 . The authors used the Sobel test to analyze the mediating effect of innovation. Based on the result the value of $\mathrm{Z}$ statistic 6,512 was higher than $\mathrm{Z}$ table with significance level 0,05 , i.e., 1,96 , so that it can be concluded that competitive advantage mediated the relationship between innovation and business performance. The moderation test in this research was conducted using the interaction test method. This test was carried out by multiplying the beta coefficient of the independent variables with the hypothesized as a moderating variable. The test result revealed a critical ratio of 4.240 and P-value of 0.00 so the hypothesis stating that business network capabilities act as a moderating variable.

The result of the study supported the first hypothesis stating that innovation has a positive influence on business performance. This is in line with Hashi and Stojcic (2012), who suggest that a company with many innovative products will increase business 
performance. Similarly, the result of this research supports the research conducted by Espallardo and Elena (2009), Junior, Pinheiro, and Valeri (2015) who suggest that innovation is the core value and competitive weapon to combat national at the and international business market.

The result of the study was also in favor of the second hypothesis which stated that innovation has a positive influence on competitive advantage. Thus, an innovation that has been done by the company can have a direct effect on a maximum competitive advantage. The result of this research is consistent with the work of Noorani (2014) and Chatzoglou, Chatzoudes (2018). They also conclude that the more innovative a company creates products, the higher the competitive advantage of the company.

The acceptance of the third hypothesis confirmed that competitive advantage could have a direct effect on business performance. Competitive advantage is the driver of business performance that enables them to sustain. It is also considered as a strategy that is beneficial for the company and should be realized unceasingly. If a company applies the policy, they will be able to win the competition both at the domestic and international level. The result of this research supports the research conducted by Hana (2013). In his study, Hana (2013) have successfully confirmed the positive effect of competitive advantage on performance measured through sales volume, profit level, market share, and return on investment. SMEs innovates in many ways such as improving product quality, minimizing motion wastes thus lowering production costs, and developing new product attributes.

The study confirmed the role of competitive advantage as a mediating variable on the relationship between innovation and business performance. Competitive advantage is highly required by every SME since it is the primary capital of the attainment of business performance. However, competitive advantage cannot stand alone if it is not supported by innovative products. Thus, innovative SMEs can gain a competitive advantage. Chatzoglou, Chatzoudes (2018) suggests that innovation will encourage the company to make and spread their ability that can support their long-term business performance. Successful innovation can make competitors find it more challenging to imitate the products, hence allowing the company to maintain their competitive advantage (Morales, et al., 2011). The result of this research is relevant to the work of Wingwon (2012).

The last hypothesis stated that business network capability moderates the relationship between disruptive innovation and business performance was also supported. Silanpaa, et al (2015) suggests that closer relationship with suppliers gives a strong contribution to company performance such as cost efficiency, quality improvement, reliability, and fulfillment of input need that is always available at any time. Relationship with the suppliers can improve information source about market development, new technology, and competitors' movement, either find potential partners or access to partners from other sectors. In other words, business networking can strengthen the correlation between innovation and business performance. Innovation done by the company will give more positive effect on the improvement of business performance since it is supported by business networking capability.

\section{CONCLUSIONS AND IMPLICATION}

In line with the results of previous rigorous studies, our results indicate that competitive advantages act as mediating variable on the relationship between innovation and business performance. Likewise, business network capability also moderate the relationship between disruptive innovation and business performance. Disruptive innovation is necessary to spur a propensity of small businesses in Indonesia. 
An implication of this assertion is that small businesses owners could place a greater focus on technology investment. For example, a small business owner with financial constraint could adopt exiting cloud technology using a smartphone. The local government could offer specialized courses and focused training to business owners who displayed an above-average motivation and intention to invest in technology. This would also imply a departure from the notion of running their businesses on simple practices alone without maximizing their effort in technology investment. Despite its methodological rigor, this study is not without limitation. The sample of the study comes from multiple sectors, therefore, future research should focus on one industry that needs disruptive innovation to achieve business performance such as manufacturing firms.

\section{ACKNOWLEDGEMENT}

We would say thank you to all SME's business owner who supported us in this paper.

\section{REFERENCES}

Badan Pusat Statistik (BPS). (2016). Statistik Daerah Kecamatan Purwokerto.

Dinas Perindustrian, Perdagangan dan Koperasi (Disperindagkop), (2017). SME's Data in Banyumas.

Duncan, M. E. (2000). The Internet Diffusion Into Small Business: Market Orientation, Identifiable Application, and Moderators od Successful Applications. Dissertation, University of Oregon.

Espallardo, Miguel Hernandez dan Elena Delgado Ballester. (2009). Product Innovation in Small Manufactures, Market Orientation and the Industry's Five Competitive Forces: Empirical Evidence from Spain. Journal of Innovation Management. 12 (4): 470-491.

Gilmore, A., Carson, D. and Grant, K. (2001). SMEs Marketing in Practice. Marketing Intelligence and Planning. Vol. 19 (01), pp. 6-11.

Hair, Joseph.F.,et al. (2010). Multivariate Data Analysis. Pearson Education International, Prentice Hall.

Hashi, I., \& Stojčić, N. (2013). The impact of innovation activities on firm performance using a multistage model: Evidence from the Community Innovation Survey 4. Research Policy, 42(2), 353366.

Hakimpoor, H. (2011). Marketing Networking Dimensions (Mnds) and Smes'Performance. Australian Journal of Basic and Applied Sciences. 10(5), 1528-1533.

Hana, U. (2013). Competitive Advantage Achievement through Innovation and Knowledge. Journal of Competitiveness. 5 (1): 82-96.

Isogawa, Daiya, Kohei Nishikawa, and Hiroshi Ohashi. (2012). New-to-Market Product Innovation and Firm Performance: Evidence from a firm-level innovation survey in Japan. No. 12-E. RIETI Discussion Paper Series.

Istanto, Y. (2010). Pengaruh Strategi Keunggulan Bersaing dan Positioning terhadap Kinerja (Survey pada Koperasi Serba Usaha di Kabupaten Sleman Yogyakarta). Buletin Ekonomi. 8 (2): 124135.

Morales, Molina et al. (2011). Geographical and Cognitive Proximity Effects on Innovation Performance in SMEs: A Way through Knowledge Acquisition. International Entrepreneurship and Management Journal. 1-21.

Noorani, I. (2014). Service Innovation and Competitive Advantage. European Journal of Business and Innovation Research. 2 (1): 12-38.

Prodromos Chatzoglou, Dimitrios Chatzoudes. (2018). The role of innovation in building competitive advantages: an empirical investigation. European Journal of Innovation Management. Vol. 21 Issue: 1, pp.44-69. 
Resende Junior, P., \& Fujihara, R. (2018). Factor Analysis On Innovation Inductors In High Performance Organizations. International Journal of Innovation, 6(3), 275-286.

Rosiana, Monica. (2015). Innovation as a Mediating Variable of Market Orientation and Business Performance and Competitive Advantage as a Mediating Variable of Innovation to Business Performance (Empirical Study on SME's in Purwokerto). Thesis. Jenderal Soedirman University, Purwokerto.

Sakchutchawan, Sut et al. (2011). Innovation and Competitive Advantage: Model and Implementation for Global Logistics. International Business Research. 4 (3): 10-21.

Shane, Scott. (2009). Why Encouraging More People to Become Enterpreneurs is Bad Public Policy. Small Business Economics. Vol. 33, issue 2, pp 141-149.

Sillanpaa, Ilkka, Khuram Shahzad, Elina Sillanpaa. (2015). Supplier Development and Buyer-Supplier Relationship Strategies- a literature review. International Journal of Procurement Management. Vol. 8: 227-250.

Sobel, M. E. (1982). Asymptotic Confidence Intervals for Indirect Effects in Structural Equation Models. Sociological Methodology. 13 (1): 290-321.

Soloducho, Letycja. (2014). Competitive Advantage: The Courage in Formulating Objectives and Expansiveness of a Strategy. Procedia-Social and Behavioral Sciences. Vol. 150: 271-280.

Supranoto, M. (2009). Strategi Menciptakan Keunggulan Bersaing Produk melalui Orientasi Pasar, Inovasi, dan Orientasi Kewirausahaan Dalam Rangka Meningkatkan Kinerja Pemasaran. Tesis. Universitas Diponegoro, Semarang.

Tallam, Sylvia C., Louice C. Maru, Charles K. Lagat. (2015). Moderating Effects of Networking Capabilities on Marketing Capabilities and Performance of Small Firms in Kenya. Journal of Marketing and Consumer Research. Vol. 15.

Wang, Guangping and C. Fred Miao. (2015). Effects of Sales Force Market Orientation on Creativity, Innovation Implementation, and Sales Performance. Journal of Business Research.

Wingwon, B. (2012). Effects of Entrepreneurship, Organization Capability, Strategic Decision Making and Innovation toward the Competitive Advantage of SMEs Enterprises. Journal of Management and Sustainability. 02 (1): 137-150.

Xayphone, Kongmanila and Yoshio Takahashi. (2009). Inter-firm Cooperation and Firm Performance: An Empirical Study of the Lao Garment Industry Cluster. International Journal of Business and Management. 4 (5).

Yan, S. and Chew, D. A. S. (2011). An Investigation of Marketing Strategy, Business Environment and Performance of Construction SMEs in China. African Journal of Business Management. Vol. 5(6), pp. 2396-2405. 